\title{
The "Blood Trinity": Robertson, Archibald and MacLean- The Canadian Contribution to Blood Transfusion in World War I
}

$\mathbf{I}^{\mathrm{t}}$ t is often said that "history is written by the victors," and although Canada and America were allies during the First World War in "medical history", the role of the American Medical Corps in introducing blood transfusion to wartime surgery appears to have completely effaced that of the Canadians. The authoritative account of the use of blood transfusion in WWI was written by British Historian Geoffrey Keynes, who by ignorance, for simplicity, or by national prejudice left out the role of the three Canadian surgeons who actually pioneered the use of blood transfusion in war surgery.

Fortunately for the Canadian legacy, the American medical historian Kim Pelis has recently made the case for a correction to the record ${ }^{1}$. The argument for the Canadian case is made in Pelis's article, "Taking Credit: The Canadian Army Medical Corps and the British Conversion to Blood Transfusion in WWI," where she details the contribution of the Canadians and the circumstances that led to their story being forgotten. The current essay tells the amazing story of blood transfusion: its development and the struggle of three innovative and courageous Canadian surgeons who brought blood to a bleeding Europe.

Although it is true that blood transfusions were already being performed in American hospitals prior to WWI, it was a trio of Canadian surgeons, Doctors Lawrence Bruce Robertson, Edward Archibald and Walter MacLean who first introduced these technologies to the British and French on the allied front. These physicians worked both on the frontlines and from within the academy in order to overcome the British preference for intravenous saline (salt water) infusion and convince the allied forces of the superiority of blood in the treatment of shock and hemorrhage. It was not until several years later, when the Americans joined the war effort, that American medical officers would further the cause and make blood transfusion the norm along the allied front.

The history of the development of blood transfusions is a story of technical obstacles and false starts. The modern development of blood transfusion was made possible in 1616, when William Harvey accurately described the circulation of blood - pumped by the heart into the lungs and body and carried by a system of veins back to the heart ${ }^{2}$. This basic insight opened the door for the experimentation conducted by 17 th century physicians. Indications for its use at this time were speculative and based on the concept of replacing diseased blood with new and healthy blood. A successful animal-tohuman transfusion was reported in 1667 and this procedure was practiced by a narrow group of physicians until a series of fatalities led to it being banned in France and England. At this point blood transfusion fell into obscurity for almost 200 years until it was revived by an English obstetrician, James Blundell.

Blundell theorized that blood transfusion could be used to treat women suffering from post-partum hemorrhage, a condition endemic to the practice of obstetrics ${ }^{3}$. He performed many experiments in animal-to-animal transfusion and in 1825 succeeded in performing his first successful human-to-human transfusion by bleeding a man into the vein of his dying wife. The transfusion reversed her hypovolemic shock and saved her from death due to post-partum hemorrhage. Despite this success blood transfusion remained a dangerous procedure fraught with technical obstacles and uncertainty and its use did not spread beyond the specialty of obstetrics.

The transfusion of blood poses a number of inherent difficulties. Foremost among these is the tendency of blood to clot immediately upon leaving the body and stick inside instruments and in the receiving patient. English transfusion practitioners first attempted to countermand this property by defibrination, dilution, and by using different apparatuses in its route between bodies, all with limited success. The procedure's unpopularity was reinforced by the work of British physiology labs that had mischaracterized blood as a merely mechanical system that transported materials and wastes ${ }^{4}$. Hemoglobin and blood's oxygen carrying function were not yet understood, and the oncotic pressure of blood proteins was not widely appreciated. Meanwhile, intravenous saline infusions had shown great success in the treatment of Cholera throughout the British colonies without any of the difficulties of blood in its acquisition or storage. By the end of the 19th century, the increased familiarity of saline, and a lack of appreciation for the qualities of blood kept blood transfusion in England as an obscurity.

During the same period, on the other side of the Atlantic blood transfusion was gaining wider acceptance. The application of Listerian principles of asepsis and sterile technique were becoming well established, and in combination with the use of ether and chloroform as surgical anesthesia, the mid to late 19th century became a time of great developments in surgery. Surgeons were becoming more adventurous in the 
procedures they undertook with the attendant consequence of increased blood loss in patients who went under the knife. These patients frequently experienced dangerous drops in blood pressure and sometimes drifted into a state of depressed consciousness followed by death. This condition came to be known as "surgical shock" and by the late 1880s it became a leading cause of surgical mortality.

George Washington Crile, an American surgeon working in Cleveland, became interested in this phenomenon after losing a friend to shock when a streetcar accident required the amputation of both of his legs. He performed much animal experimentation on the causes and treatment of shock and noted the severe drop in blood pressure that led to decreased perfusion and ultimate failure of the body's vital organs. He came to realize that the brain imposed a time limit - minutes without perfusion meant death. These patients were often treated with intravenous saline in an effort to boost their blood pressure and maintain organ perfusion. Crile became convinced that saline infusion provided only temporary support inevitably followed by a drop in pressure and deeper decline in condition ${ }^{5}$. He theorized that transfused blood would remain in the blood vessels and prove of lasting value to patients suffering from shock.

Crile struggled with the technical aspects of transferring blood from the donor into the patient until he learned of French surgeon Alex Carrel's suture technique which had been developed for transplant surgery and which Crile applied to blood transfusion by directly sewing the donor's radial artery onto a vein of the recipient's $\operatorname{arm}^{6}$. Crile beat Carrel in performing the first "anastomosis" human-tohuman transfusion and thus led the American return to blood transfusion.

In the pre-WWI years, American centers were working on many techniques to make transfusing blood safer and easier. In New York, Richard Lewisohn was working with the anticoagulant citrate to prevent blood clotting. Reuben Ottenburg was further developing Landsteiner's work on blood groups, agglutination and hemolytic reactions. Edward Lindeman was developing the syringe-cannula method of blood transfusion and in Boston, A. R. Kimpton and J. H. Brown developed a paraffin-coated collecting tube that delayed the clotting of blood, buying more time for its transfusion.

When war broke out in 1914, due to an unfortunate system of pacts and alliances, most of the world's great powers set out upon one another. Canadians rallied to the cause of their "motherland" and by the time the war was barely a year old the Canadian trio was stationed behind British lines on French and Belgian soil.
New technologies would make this war the bloodiest the world had ever seen. Machine guns firing 400 rounds per minute and shrapnel from artillery shelling quickly forced both sides to dig down and rely on the protection of trenches. Casualties arrived in vast numbers, but the relatively fixed nature of trench warfare enabled a relatively sophisticated system of casualty clearing and trauma care to be developed. Stretcher bearers pulled the wounded from where they fell in "no man's land" through the trenches to a horse drawn ambulance which would then take them to the casualty clearing stations (CCS) 5 to 10 miles behind the lines. The journey to the CCS was rough and the condition of the injured was worsened by cold, dehydration and continued bleeding. Surgeons at casualty clearing stations were faced with the challenge of saving these soldiers. Victims were triaged into those with minor injuries, those in need of immediate medical attention and those who were hopeless and condemned to die. Fractured femurs, penetrating wounds to the abdomen and multiple bleeds often turned into gangrenous lesions: these injuries were often followed by the onset of "shock." Pale, cold to the touch, with thin pulse and failing consciousness, these victims were generally relegated to the ranks of the hopeless. Canadian surgeons, however, resorted to the then controversial procedure of blood transfusion in an effort to save these soldiers. Three Canadian surgeons in particular made significant contributions to the introduction of blood transfusions into the British medical system during the war: Lawrence Bruce Robertson, Edward Archibald and Walter MacLean.

The Trio's Paths to the Front...

Lawrence Bruce Robertson (1885-1923) was born in Toronto, son of a well-to-do merchant family of Scottish ancestry ${ }^{7}$. He attended the University of Toronto in 1902 where he earned a BA and a medical degree before interning at the Toronto Hospital for Sick Children. He completed a residency at Bellevue Hospital, NY where he trained in first aid and ambulance work, areas that the university had pioneered during the nineteenth century. It was here that he learned Lindeman's syringe-cannula technique of blood transfusion.

The technique involves the introduction of two cannulae: one into the vein of the donor's arm and the other into the vein of the recipient. Syringes were then used to draw blood through the donors's cannula and inject it through that of the recipient, making sure to flush the cannula with saline after each syringe to prevent clotting. Although the technique was cumbersome and required a pair of surgeons to perform, it was an improvement on Crile's procedure of blood transfusion by "anastamosis". Upon returning to Toronto Hospital for Sick Children, Robertson introduced blood transfusion into the hospital treating conditions ranging from hemorrhagic 
disease of the newborn to severe infantile malnutrition.

Britain declared war on Germany on August 4, 1914 and on August 5, Robertson volunteered for service ${ }^{7}$. He was commissioned into the Canadian Army Medical Corps and sailed from Halifax to England in April the following year. He was assigned to the No. 2 Canadian Casualty Clearing Station and by September 17, 1915 was in France.

Edward Archibald (1872-1945) was born in Montreal ${ }^{8}$. He studied medicine at McGill University and became a lecturer in surgery at McGill and a surgeon at the Children's Memorial Hospital and the Royal Victoria Hospital. He was considered an expert on head injuries and cancer surgery. In December 1914 , in preparation for the war, he went on a pilgrimage to Crile's clinic in Cleveland to learn about the treatment of shock first hand. McGill, where Archibald taught, had decided to establish a wartime general hospital and by June 1915 Archibald was in France armed with six Kimpton-Brown tubes and prepared to apply the blood transfusion techniques he had learned from Crile.

In France both Archibald and Robertson were stationed at general hospitals and although far from the front lines they were successfully performing transfusions for secondary hemorrhage on soldiers cleared from the front. By the spring of 1916 Archibald found himself much closer to the fighting on the front as a surgeon at a CCS.

Walter MacLean (1885-1917) was born in Macleod, Alberta, but moved to Halifax at a young age where he attended medical school at Dalhousie University. He was top of his class at Dalhousie and captain of his rugby team. His success on the pitch mirrored that in the operating room where he became a pioneering abdominal surgeon. He started a surgical practice in Glace Bay, Nova Scotia, but when war broke out he left his busy practice to join the war effort. In France, MacLean worked as a surgical assistant to Archibald in a CCS.

Thus Robertson, Archibald and MacLean found themselves near the frontlines in the early stages of the war. They had the training and equipment to perform blood transfusions and would be met with hundreds of times more cases of shock and hemorrhage than would ever have been encountered in civilian practice. Soldiers suffering from shock were known from grim experience to be poor candidates for surgery. They were thus, in the British system of triage, often relegated to the "moribund wards" or "dying tents," where they were kept as comfortable as possible by attending nurses until they died. If doctors were not occupied with the more salvageable cases, they might attempt to restore them with intravenous saline as the British preference for saline had remained pronounced despite the mounting number of casualties. In fact, the British Medical Journal, reviewing Crile's 1907 work on blood transfusion went so far as to state that: "surgeons, we imagine, will find no good reasons given here for abandoning the safe and simple method of saline injection."

But the circumstances of the war were such that saline's ineffectiveness in treating shock soon became impossible to ignore. An exponential increase in the number of shock casualties was caused by the Battle of the Somme, a joint British/Canadian and French offensive intended to break the German line and relieve pressure from the Battle of Verdun ongoing in the south. On July 1st, 1916 after 5 days of artillery bombing and mining of the German line the allied soldiers, braving barb wire, artillery and machine guns, rushed the German trenches. It was the bloodiest battle in British history. The British suffered 60,000 casualties on the first day alone and by the end of the battle in November 1916 casualties numbered at 420,000 - of whom 100,000 died. During the treatment of these vast numbers of casualties, it became obvious that saline infusion alone was ineffective for the treatment of shock and hemorrhage.

That same summer, while reports of the casualties of the Battle of Somme continued to roll in, Robertson's first article was published in the British medical press. It was appropriately titled "The transfusion of whole blood: a suggestion for its more frequent employment in war surgery." In this, and subsequent articles, Robertson made the case for blood transfusion as the best treatment for blood loss through acute hemorrhage. He suggested that transfused blood provided a more permanent addition to the body's tissues and carried coagulation elements as well as complement and antibodies to fight infection. He described how "the addition of blood often carries the patient over a critical period, and assists his forces to rally to withstand further surgical procedures [often amputation] necessitated by the infective process."

At this time, Archibald and MacLean were also successfully performing blood transfusions. They worked side by side and became increasingly proficient in the surgical treatment of head and abdominal injuries. In 1917 they published an article together entitled, "Observations upon shock, with particular reference to the condition as seen in war surgery." 10 Archibald, whose funds would not allow him to prolong his stay, returned to Canada leaving MacLean in charge of their CCS. In the spring of 1917 MacLean's CCS was to undergo restructuring. Blueprints of MacLean's camp show that he shaped his new operating facilities to include a new building called the "resuscitation hut" in place of the "moribund ward". In essence, there were no more "hopeless cases"- with blood transfusion and skilled surgical hands all patients might be saved $^{1}$.

The resuscitation ward became the stage where British surgeons could see for themselves the promise of blood 


\section{Health Science Bookstore}

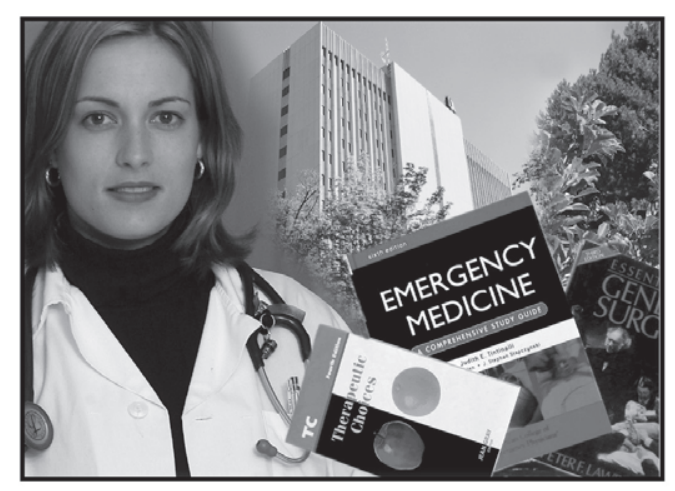

Service, Selection \& Satisfaction

Let us be your source for

Medical Reference Books

Visit us at:

Carleton Campus Bookstore

5981 University Avenue

Dalhousie Dentistry Building

Tel: 902.494 .6701

Email: bookstore@dal.ca

\section{DALHOUSIE \\ UN IVERS I T Y \\ BOOKSTORES \\ www.dal.ca/bookstore}
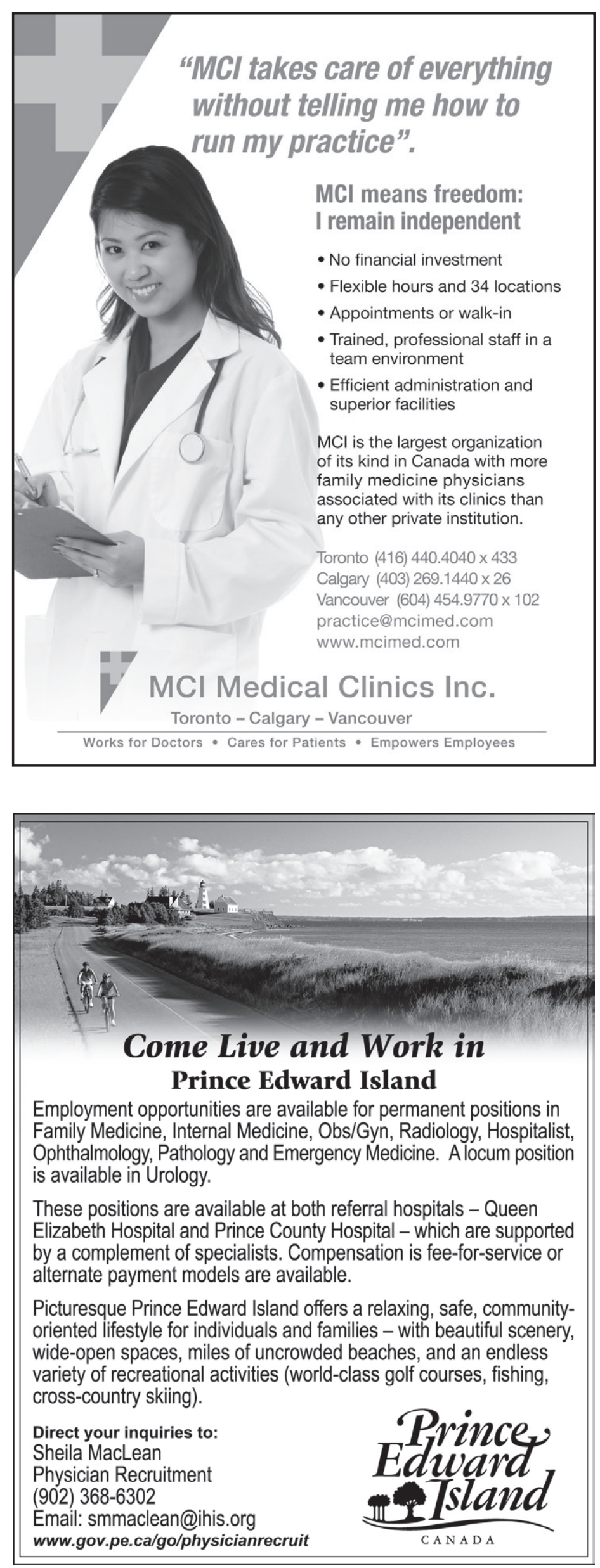

Francis \& Associates is a specialist recruitment agency placing all types of health professionals including Diagnostic, Nursing, Rehabilitation - Physiotherapist, Occupational Therapists, Hearing Specialists, Speech Language Pathologist, Audiologists, Nutrition, etc. positions throughout Canada. We specialize in Medical Services and we have been doing this for over a decade.

We have many positions available and are currently recruiting qualified Health Professionals for permanen and contract positions for various organizations, hospitals and private facilities across Canada.

There is absolutely no cost or obligation to registering with our company. We are just another avenue to know of opportunities available across Canada.

Send us a copy of your resume and we will contact you to find out more about what type of position you are looking for and what geographical area in Canada and when you are available to start work. We will also provide you with further details about opportunities in those areas.

VISIT OUR WEBSITE FOR MORE DETALLS ABOUT OUR JOB OPPORTUNITIES ON WWW.FRANCIS-ASSOCIATES.COM - TAKE ADVANTAGE OF THIS FREE SERVICE!

CALL US AND Find OUT MORE: TOLL FREE 1-888-837-2624 TORONTO:416-267-5626 OR FAX: 416-267-9446.
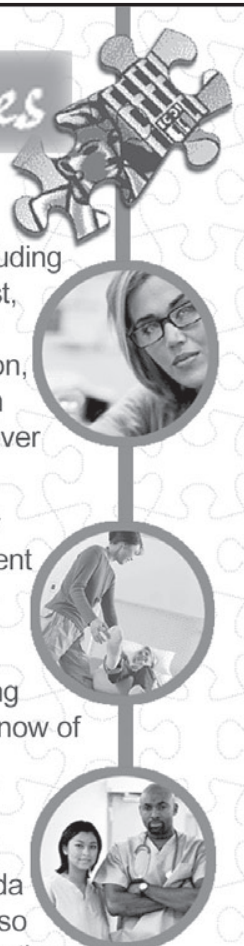

e n 
transfusion for the treatment of shock and hemorrhage. British surgeon, John A. Hayward, writes in his war diary, "The effect of transfusion was in some cases miraculous. I have seen men already like corpses, blanched and collapsed, pulseless and with just perceptible breathing, within two hours of transfusion sitting up in bed smoking, and exchanging jokes before they went to the operating table." 11

Despite the dramatic success of these early transfusions, working with blood remained a very technically difficult procedure. The syringe-cannula method used by Robertson and the Kimpton-Brown technique that Archibald had preferred before the war were elaborate procedures that required specialized skills and were difficult to perform in a busy CCS. Archibald, while stationed in France, was the first to bring Lewisohn's citrate method of blood transfusion to the war. ${ }^{8}$. The technique, which is still used today, involved bleeding the donor into a sterile container containing a solution of the anticoagulant citrate. The blood could then be transfused or stored on ice for later use. Archibald extolled the merits of this new transfusion procedure in the British medical press. He described the process as so easy it "can be done by a junior medical officer" and that "one can deal with the blood as one would deal with saline." 12 This innovation removed a huge technical obstacle to the use of transfusions and paved the way for blood banking where a reservoir of blood could be accumulated before any major offensive and carried forward along with the advancing troops.

Cleary these three Canadians have contributed much to the development of blood transfusion in trauma care and saved many lives in the process. Why then has their story been forgotten? Tragically, in autumn 1917, a plane dropped a bomb on MacLean's CCS, killing him, destroying the records of his work and research, and leaving behind his wife and unborn daughter. Robertson, towards the end of the war was plagued with illness and was even denied permission to return to the front in the autumn of 1917. Although he continued to work in Toronto at the Hospital for Sick Children, developing a technique called "exsanguination-transfusion" for children with toxic conditions, he succumbed to the "Spanish Flu" in 1923. Archibald survived to lead a prosperous career in Montreal, however, he had been forced to leave the war early, in the autumn of 1916. Thus, when America declared war on Germany on April 6th, 1917 and Crile and his team of medical officers began arriving in France in late May 1917, the three Canadian blood transfusion pioneers were, for the most part, no longer present ${ }^{1}$. Effectively, there was a changing of the guard and the next set of transfusion practitioners, including Keynes, would go on to write the history of blood transfusion in WWI never having witnessed the contributions of the Canadian trio. The American team took over where the Canadians left off establishing the procedure widely across the Front. George Crile and the Americans claimed "victory", and in his autobiography - written in large part posthumously by his wife - Crile takes credit for founding the "resuscitation ward" and for introducing blood transfusion to the war.

Evidence of the Canadian contribution to this revolution is available for those who know where to find it: in their diaries, publications in peer reviewed journals and observational accounts. In June, 1917, Sir Anthony Bowbly, British consulting surgeon to the front, published this account in the British Medical Journal: "The main advance in treatment [of hemorrhage] has consisted in a return to the practice of transfusion of 'whole blood' which has in great measure displaced the unsatisfactory saline infusion. For the popularization of this method we are mainly indebted to our Canadian colleagues in France." ${ }^{13}$ Yet this contribution is not reflected in the authoritative historical accounts of transfusion history written shortly after the war. Unfortunate circumstances begot the Canadians and their story was all but forgotten. Now history must be rewritten to include the story of Lawrence Bruce Robertson, Edward Archibald and Walter MacLean.

\section{Hazen Burton}

Class of 2010, Faculty of Medicine, Dalhousie University

\section{REFERENCES}

1. Pelis K. Taking credit: The Canadian Army Medical Corps and the British conversion to blood transfusion in WWI. Journal of the History of Medicine 2001;56:238.

2. Mulaf NSR. History of blood transfusion. Journal of the History of Medicine 1954;9:59-107.

3. Baskett TF. James Blundell: The first transfusion of human blood. Resuscitation 2002;52:229-233.

4. Pelis K. Blood standards and failed fluids: Clinic, lab, and transfusion solutions in London, 1868-1916. History of Science 2001;39:185-213.

5. Lee JA, Widmann WD, Hardy MA. George Washington Crile, MD. Curr Surg 2005;62:415-418.

6. Crile G. The technique of direct transfusion of blood. Ann Surg 1907;46:329332.

7. Pinkerton PH. Canada's transfusion medicine pioneer: Lawrence Bruce Robertson. Transfusion 2001;41:283-286.

8. Pelis K. Edward Archibald's notes on blood transfusion in war surgery-a commentary. Wilderness Environ Med 2002;13:211-214.

9. Robertson LB. The transfusion of whole blood: A suggestion for its more frequent employment in war surgery. Br Med J 1916;2:38-40.

10. Archibald EW, MacLean WS. Observations upon shock, with particular reference to the condition as seen in war surgery. Ann Surg 1917;66:281-287.

11. Hayward, John A (1930). "Memoirs \& Diaries: a casualty clearing station"; $<$ http://www.firstworldwar.com/diaries/casualtyclearingstation.htm> (20 June 2008)

12. Archibald E. A note upon the employment of blood transfusion in war surgery. J R Army Med Corps 1916;27:636-644.

13. Bowlby A, Wallace C. The development of British surgery at the front. Br Med J 1917;1:705-721. 